\title{
Digestive strategies of the high Arctic Svalbard reindeer
}

\author{
W Sormo 2, TD Josefsen 2, SD Mathiesen 1 \\ 1Department of Arctic Biology and Institute of Medical Biology, University of Tromso, 9037 Tromso ; \\ 2Department of Arctic Veterinary Medicine, Norwegian College of Veterinary Medicine, 9005 Tromso, Norway
}

Svalbard reindeer (Rangifer tarandus platyrhynchus), one of seven sub-species of Rangifer, are among the most northerly herbivorous ungulate in the world. They survive under the most austere nutritional conditions in the high Arctic archipelago of Svalbard $\left(77^{\circ}\right.$ $81^{\circ} \mathrm{N}$ ) with seasonal changes in day length. These reindeer live all year round in ice-free valleys and on exposed polar plateaux. The vegetation varies from valleys with tundra vegetation and a rich plant cover to areas with poor plant cover. Plant growth is limited to a period of two months in summer, when quality and availability of the plants are high. Earlier reports conclude that the Svalbard reindeer eat plants like grasses, rich seed heads and mosses during the year (Punsvik et al, 1980, Proc of the 2nd Int Reindeer and Caribou Symp, 115-124; Persen et al, 1983, Acta Zool Fenn, 175, 35-37), but the chemical composition of the cell-wall fibre fraction in the plants is not known. The Svalbard reindeer have high population densities of cellulolytic micro-organisms in the rumen and caecum (Orpin et al, 1985, Appl Environ Microbiol, 50 (1), 144-151; Mathiesen et al, 1987, Appl Environ Microbiol, 114-118), which might reflect a poor quality diet. The digestive strategies of the animal are poorly understood. Reindeer are normally classified as intermediate mixed feeders. The present studies characterise some digestive strategies in the gastro-intestinal system of the high Arctic Svalbard reindeer on different winter pastures.
Six Svalbard reindeer were shot in the middle of April (late-winter) in two areas. The botanical and the chemical composition of the rumen contents were analysed. The anatomy of the gastro-intestinal system was examined, and cellulose degradation in the ruminal and caecal contents was recorded (Terry and Tilley, 1963, $\mathrm{Br}$ Grassid Soc, 18,104-111).

The rumen contents of the Svalbard reindeer from an area with high biomass, consisted of mosses and dry grass, and had a high content of cellulose and hemicellulose, but a low content of protein. Svalbard reindeer from marginal grazing areas were found to select more nutritious plants like Saxifraga sp., with low content of cellulose and hemicellulose, but with a high content of lignin-like substances and protein. The gastro-intestinal system of the Svalbard reindeer is characterised by a short intestine and a mean large intestine/small intestine ratio of 0.53 (SD 0.06). The hind gut is large compared to Rangifer $t$. tarandus, but the rumen size does not differ much from the continental reindeer species. Svalbard reindeer have large omasa (402.0 (SD 82.8) $\mathrm{g}$ in a 56.0 (SD 7.8) kg reindeer) which function hitherto is poorly understood. The utilisation of cellulose in the rumen was low compared to that of reindeer in Norway, but seems to be compensated by high cellulose degradation capacity of caecal micro-organisms. This support the hypothesis that Svalbard reindeer are highly adaptable ruminants, in which the gastro-intestinal system has developed many similarities to that of concentrate feeders. 